\title{
Çakallar Monojenik Sinder Konisi'nin Jeolojisi ve Yığışım Lapilli Oluşumları (Kula Na-Alkali Volkanizması-Batı Anadolu)
}

\author{
Geology of the Çakallar Monogenic Cinder Cones and \\ Formation of the Accretionary Lapilli (Kula Na-Alkaline \\ Volcanism-Western Anatolia)
}

\section{Cüneyt Akal ${ }^{1 \oplus,}$, Yeşim Yücel Öztürk ${ }^{1^{*}}$}

${ }^{1}$ Dokuz Eylül Üniversitesi Mühendislik Fakültesi Jeoloji Mühendisliği Bölümü, İzmir, TÜRKIYE

*Sorumlu Yazar / Corresponding Author*: yesim.yucel@deu.edu.tr

Atıf șekli/How to cite: AKAL, C., YÜCEL ÖZTÜRK, Y. (2019). Çakallar Monojenik Sinder Konisi'nin Jeolojisi ve Yığışım Lapilli Oluşumları (Kula Na-Alkali Volkanizmast-Batı Anadolu). DEUFMD, 21(61), 155-171.

$\ddot{0} \mathbf{z}$

Yığışım lapillileri esas olarak cam veya camın alterasyon ürünleri olmak üzere tamamen kırıntılı volkanik malzemeden oluşan yaklaşık bezelye büyüklüğünde yapılardır. Yığışım lapillileri, bunları üreten volkanizmanın doğası, volkanizma ürünü kayaçları etkileyen çökelim sonrası değişimler ve stratigrafinin belirlenmesi ile ilgili önemli bilgiler sağlamaktadır. Bu şekilde, volkanik faaliyetlere bağlı olarak gelişen ve bu faaliyetlerin meydana geldiği ortam ve köken açısından önemli ipuçları sağlayan yı̆̆ışım lapillileri (accretionary lapilli) Kuvaterner yaşlı Na-alkali Kula volkanizmasının (Batı Anadolu) en genç (11.21 ka) ürünü Çakallar Sinder Konisi çevresinde yaygın șekilde gözlenmektedir. Çakallar volkanizması şiddeti az patlamalı-piroklastik püskürme ürünü ince kül yağması ile başlamıştır. Çok katmanlı kül tabakası arasında, eş boyutlu tanelere sahip, kül ara maddeli küresel yığıșım lapilli zengin tabaka bulunmaktadır. İkinci evre patlamayla yığıșım lapillilerin üzeri ince kül yağması ile tekrar örtülmüștür. Mezolitik dönem insanları Gediz nehri vadisine doğru inerken Çakallar konisinin etrafındaki yumuşak çamur kıvamındaki son kül tabakası üzerinde mükemmel şekilli ayak izlerini bırakmışlardır. Volkanik aktivitenin en son ve şiddetli evresinde Çakallar konisi son şeklini almıştır. Bu son evreye de tanıklık eden Mezolitik dönem insanları, sığınak olarak kullandıkları gnayslar üzerine şiddetli volkanik faaliyeti resimlemiş ve el izlerini bırakmışlardır.

Çakallar Sinder Konisi'ne ait Zon-tipi yığışım lapillileri volkanik aktive sırasında gelişen elektrostatik çekim ve buhar fazının etkin olduğu koşulları yansıtmaktadır. Yığışım lapillileri Çakallar konisin püskürttüğü kül-yüklü bulutta, buhar fazının yoğunlașması ile gelișen yağıș sırasında yağmur damlalarının içine aldığı kül yığıșımlarının birikmesiyle gelişmiştir ve dolu taneleri șeklinde ilk ince kül tabakası üzerine düşmüştür.

Anahtar kelimeler. Yığıșım lapilli, Çakallar Sinder Konisi, Kula volkanizması, Batı Anadolu

\section{Abstract}

The accretionary lapilli are approximately pea-sized particles, consisting essentially of clastic volcanic material, mainly glass or glass alteration products. The accretionary lapilli provide useful information about stratigraphy, the nature of volcanism producing them and post-depositional changes affecting the rocks that they contain. In this way, accretionary lapilli, which develop due to volcanic activity and 
provide important clues in terms of the environment and origin of these activities, are widely observed in the Çakallar Cinder Cone (Western Anatolia) which is the youngest (11.21 ka) product of the Quaternary Na-alkaline Kula volcanism. The Çakallar volcanism began with fine ash fall which is a low-explosive-pyroclastic eruption product. The ash fall has multiple layers and between these layers, there is a spherical accretionary lapilli-rich intermediate layer with equigranular grain and interstitial ash material. With a second stage explosion, accretionary lapilli has been covered by a very fine-ash fall. People, who lived in the Mesolithic Epoch, left their perfectly shaped footprints on this fine ash-layer which had a soft mud-like viscosity, when they descended towards the Gediz Valley. During the last destructive stage of the volcanic activity, the Çakallar cone has taken its final shape and has thrown volcanic bombs at nearby distances, reaching the meter-sized. The people of the Mesolithic Epoch who witnessed this last stage, also left their hand marks and depicted this volcanic activity on the gneisses (called as the Kanl Kaya) that they used as shelters. It is emphasized that the accretionary lapilli of the Çakallar Cinder Cone, which is defined as rim-type accretionary lapilli, has probably been formed due to the conditions where the volcanic-related vapor phase was active during the Western Anatolian Quaternary volcanism. These structures probably developed with accumulation of ashfalls in the raindrops during the raining (precipitation) caused by the condensation of the vapor phase in an ash-charged volcanic cloud and fell into the form of hail-like grains.

Keywords. Accretionary lapilli, Cakallar Cinder Cone, Kula volcanism, Western Anatolia

\section{Giriş}

Lapilli (lapillus), volkanik püskürmelere bağlı olarak gelişen 2-64 mm çaplı piroklastik (sıcak volkanik kül) parçacıklardır [1 - 3]. Yığıșım lapilli (accretionary lapilli), patlamalı volkanik püskürme ürünü piroklastik külün $(>2 \mathrm{~mm}$ ) elektrostatik çekim ile kümelenmesi ve patlama ile iliş̧ili oluşan buhara ait damlalar içinde yine çekim ile yığıșması sonucu gelișmiș farklı boyutlara $(\mathrm{cm}-\mathrm{mm})$ sahip sferoidal kül toplarıdır [3].

Bu yapıların çoğu freato-magmatik püskürmeler sırasında oluşsa da su içeren diğer şiddetli volkanik püskürmeler de bu yapıları üretebilmektedir [1 - 5]. Bunun yanında, atmosferik su buharı yığıșım lapilli olușumu için gereken nemli ortam koşullarını da sağlayabilmektedir. Püskürme bulutlarındaki parçacık yüzeyleri üzerinde yoğunlaşan sıvılar, kalsiyum sülfat ve sodyum klorür gibi, yığışım lapillilerinin toprağa çarpmasından önce bünyesinde bulundurabileceği asit çözeltiler de olabilmektedir [5].

Yeryüzünde volkanik faaliyetlere bağlı gelișen ve oldukça yaygın şekilde gözlenen yığışım lapilli yapılarının olușumları ve kökenlerine ilişkin birçok araștırma yer almaktadır [1-8]. [2] tarafından yığıșım lapillisi gelișim mekanizmalarına dair, devir-daim rüzgâr tünellerinde deneysel incelemeler gerçekleştirilmiştir. Deneysel çalışma, yığışım lapillilerinin sıvı ile kaplanan kül parçacıkların birbiri ile çarpıșması ve yüzey gerilim kuvvetleri hatta ikincil mineral büyümeleri sonucu bağlanma ile kontrol edildiğini göstermiștir. Yığışım lapillisinin büyümesi sırasında ise belirli parçacık boyutlarının farklı zamanlarda küresel yapı üzerinde yoğunlaşmasıyla yığıșım lapillisi içyapısında konsantrik tane boyu zonları da gelişebileceği gözlenmiștir. Rüzgâr tüneli hava akımındaki kül parçacıkların boyut analizi ve büyüyen yığışım lapillisine yapışan parçacıklar değerlendirildiğinde, kümelenme katsayısının yüksek oranda tane boyutuna bağlı olduğu saptanmıştır [2]. Püskürme bulutlarında yığışım lapilli büyümesine dair araştırıcılara ait bu teorik simülasyon, $0.7 \mathrm{~mm}$ çap için $0.5 \mathrm{~km}$ ve $20 \mathrm{~mm}$ çaplı maksimum boyut için 10 km'lik kül bulutu kalınlıklarının olması gerektiğini öngörmüştür.

Doğrudan gözlemler, ince taneli partiküllerin çoğunun volkanik bulutlardan (plumes) kül yağması olarak düștügünü göstermiștir [9-11]. Üretilen yığıșım lapillilerinin morfolojileri, katı (piroklastik kül), sıvı ve gaz fazlarını içeren bulut içindeki fiziksel ve kimyasal süreçlerin kompleks etkileşimi ile kontrol edilmektedir. Sıvı içeriğine göre yapılan sınıflanmalar yığıșım lapillilerinin, kuru yüksek-gözenekli lapillilerden, nemli düşük-gözenekli lapillilerden, çamur yağmurundan ve özellikle parçacık içermeyen sıvı damlalarından oluşturabileceğini göstermektedir [2]. Düşük sıcaklıklarda sıvı fazların katılaşması ile yığıșım lapillileri bileșen parçacıklarına göre çok daha yüksek hızlarla 
düşebilmektedir [12]. Bu nedenle, agregalașma, ince partiküllerin volkanik kül bulutlarından (plumes) uzaklaşmasını hızlandırmakta ve çok çeşitli yığışım lapilli boyutlarının eşzamanlı olarak birikmesine izin vermektedir.

Kula Na-Alkali volkanizması ile ilgili yapılan çok sayıdaki çalışma volkanizmanın fiziksel, yapısal, petrolojik, petrojenetik ve jeokronolojik verilerini ayrıntılı şekilde içermektedir [13- 33].

$\mathrm{Bu}$ çalıșmanın amacını ise Kula volkanik alanında gözlenen Kuvaterner yașlı Çakallar sinder konisinin jeolojisi ve burada saptanan yığışım lapillilerinin oluşum mekanizması ve petrografik özellikleri oluşturmaktadır.

Çalıșma alanı aynı zamanda, yoğun nem ile pekleşmiş kül örtünün üst seviyelerinde Mezolitik dönemde yaşamış insanlara ait ayak izlerini $[34,35]$ ve bu insanların bölgede gelișen volkanik faaliyeti kutsal sembolleri ile resimledikleri Kanlı Kaya'yı [36] bulundurması nedeniyle de oldukça önemli bir jeopark alanıdır (Şekil 3a). Ayak izleri, temeli oluşturan Menderes Masifi metamorfitlerini art arda gerçekleşen birkaç şiddetli patlamayla örten ince kül tabakası üzerinde bulunmaktadır (Şekil 3b). Böylece, bu çalışmada elde edilen yığışım lapillilerin oluşumları ve yaş ilişkilerine dayanan önemli verilerle, bir jeopark alanı olan Kula volkanik sahasında gözlenen ayak izleri ve Kanlı kayanın tarihçelerine ilişkin de net sınırlamalar getirilebilmektedir.

\section{Bölgesel jeoloji}

Tersiyer ve Kuvaterner yaşlı volkanik kayaçlar, Hellenik dalma-batma zonunun yay gerisine ait bir bölgesi olan Batı Anadolu'nun önemli bir bölümünü kapsamaktadır (Șekil 1). Batı Anadolu volkanizmasının güneye doğru gençleşmesi, birçok araştırıcı tarafından yiten Afrika levhasının geri hareketine bağlanmaktadır [37, 21]. Aynı zamanda bu süreç, üst levhada önemli derecede kabuk genleșmesine $[38,39]$ ve ilișkili olarak litosferik mantonun incelmesine $[17,40]$ neden olmuştur. Batı Anadolu'da, KKD-GGB uzanımlı genleşmeye bağlı açılma geç Oligosen-erken Miyosen'de bașlamıștır. Bu açılma, D-B yönlü normal faylarla kontrol edilen grabenlere, sıyrilma fayları ve aşınma ile Menderes Masifi'ne ait metamorfik kayaçların yükselerek yüzeylenmesine neden olmuştur [41-46]. Bu grabenlerin en büyükleri Büyük Menderes ve Gediz grabenleridir. Kula Na-Alkali volkanizması, bölgede temeli oluşturan kuzey
Menderes Asmasifi'nde (Gördes Asmasifi) gözlenen en genç volkanik faaliyeti temsil etmektedir.

\section{Kula volkanizmasının bölgesel jeolojisi}

Batı Anadolu'da Gediz Grabeni ile Simav Grabeni arasında bulunan Selendi havzasında yer alan Kula volkanitleri, yaklaşık 80 adet bazaltik sinder (kül) konisi, 5 maar, 8 sıçratma konisi, 6 tümülüs ve bunlarla bir arada bulunan Kuvaterner yaşlı bazaltik lav akmalarından olușmaktadır. Sinder koniler ana olarak skorya, bazaltik lav akmaları (alkali olivin bazaltlar, bazanitler ve fonotefritler) ve ikincil tüf ve tefra çökelimlerinden oluşmaktadır [48, 13, 17, 23, 32]. Birçok araştırıcı, KD-GB yönelimli havzaları içeren bölgede volkanizmanın kabuksal incelme ile geliştiğini belirtmiştir [49-51, 15, 23, 26, 29]. Kula volkanik ürünlerinin ayrıntılı petrografik ve jeokimyasal çalışması [32] tarafından gerçekleştirilmiştir. Buna göre, bölgede gözlenen lavlar, yerleșimleri ile ilișkili olarak porfirik, hipokristalen ve camsı doku sunmaktadır. Bazanitten fonotefrite kadar bileşimsel olarak değișen volkanik kayaçların lav fasiyeslerinin genel mineral bileşimleri benzerlik göstermekte olup olivin, klinopiroksen, hornblend, plajioklas, nefelin ve lösit kristalleri içermektedir. Hornblend kristalleri volkanik faaliyetin ikinci evresine ait lav akmalarında ortaya çıkmaktadır [32].

Jeomorfolojik kriterlerin yanısıra K-Ar yaşlandırmasına göre de bölge, aralıklı üç ayrı patlama fazını yansıtmaktadır (Sekil 2). İlk evre (b1) 1,94 \pm 0,16 - 0,99 $\pm 0,11$ milyon yll K/Ar (hamur) ve $\mathrm{Ar} / \mathrm{Ar}$ (amfibol) yașl vermektedir $[51,52,19,23]$ ve artarda şiddeti fazla olmayan patlamalarla gelişen, kalınlığı yaklaşık $35-45 \mathrm{~cm}$ olan cüruf kül ile başlamakta ve bunu iyi gelişmiş sütun yapıları içeren plato bazaltlar izlemektedir. İkinci evrede monojenetik volkanlar olușmuștur ve Kula volkanizmasının en yüksek hacimli lavlarına eşlik etmektedir (b2, 299 bin \pm 20 yıl 50 bin \pm 9 yıllık K/Ar hamur ve amfibol yaşı [ 51 , $19,23])$. Son evre ise, (b3, 25 bin \pm 7 yll -4 bin \pm 2 yıl K/Ar (hamurdan) $[53,19,23]$ yüzeyi oldukça pürüzlü, gözenekli, keskin kenarlı bloklu, sütun soğuma çatlakları içeren aa-tipi bazaltik lav akmaları ile temsil edilmektedir [32]. Bu verilerin dıșında, [33], bölgedeki en genç lav akıntıları ve kül konilerinin yaşını belirlemek için bazaltlardan alınan olivin fenokristalleri ve ksenolitlerden elde edilen kuvars minerallerinden yapilan ${ }^{3} \mathrm{He}$ ve $10 \mathrm{Be}$ yaşlandırma yöntemini kullanmışlardır. 


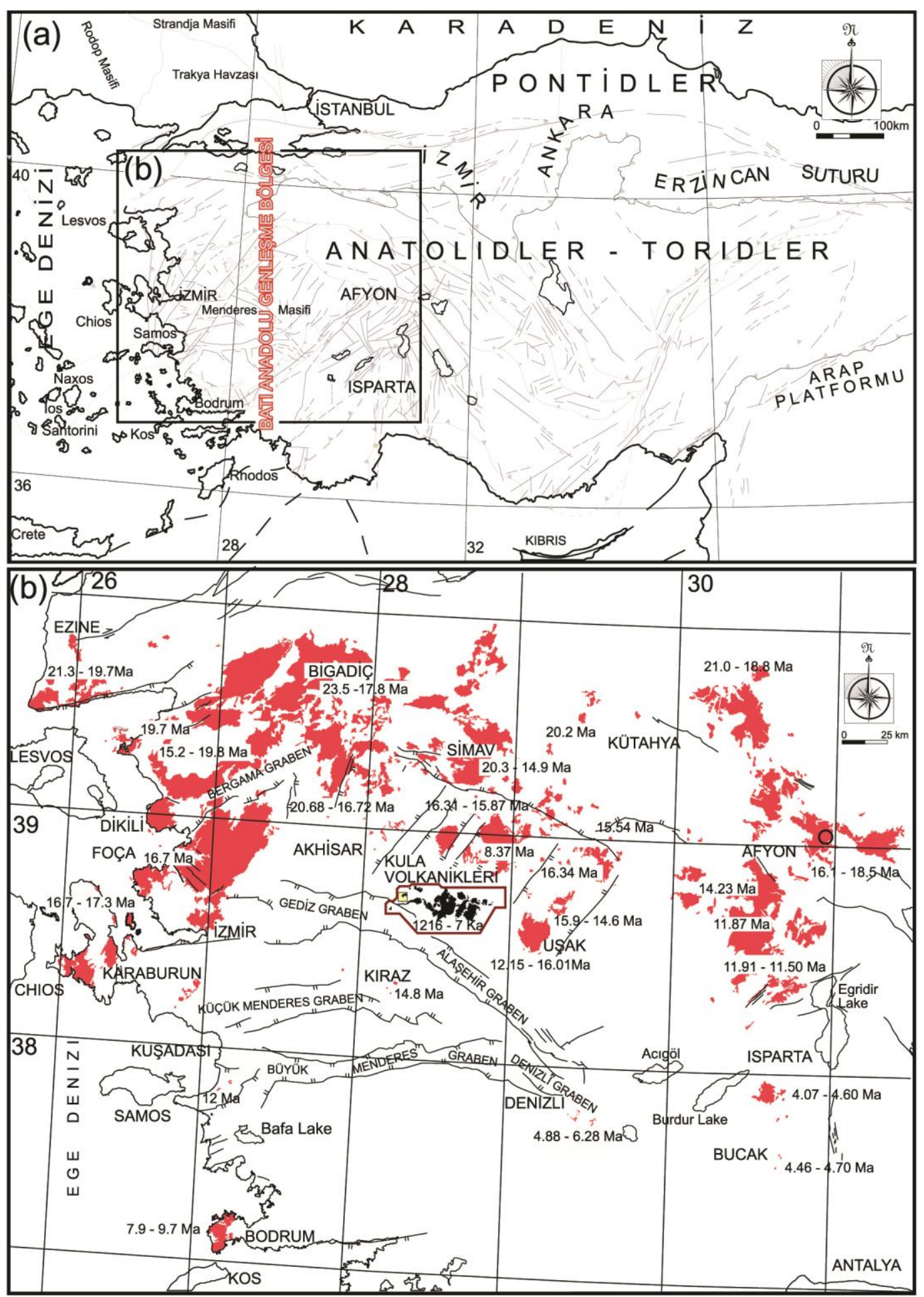

Şekil 1. a. Anadolu'nun basitleștirilmiş tektonik haritası. b. Önemli volkanik sahaları (kırmızı) ve bunların yașlarını gösteren Batı Anadolu haritası [40]. 


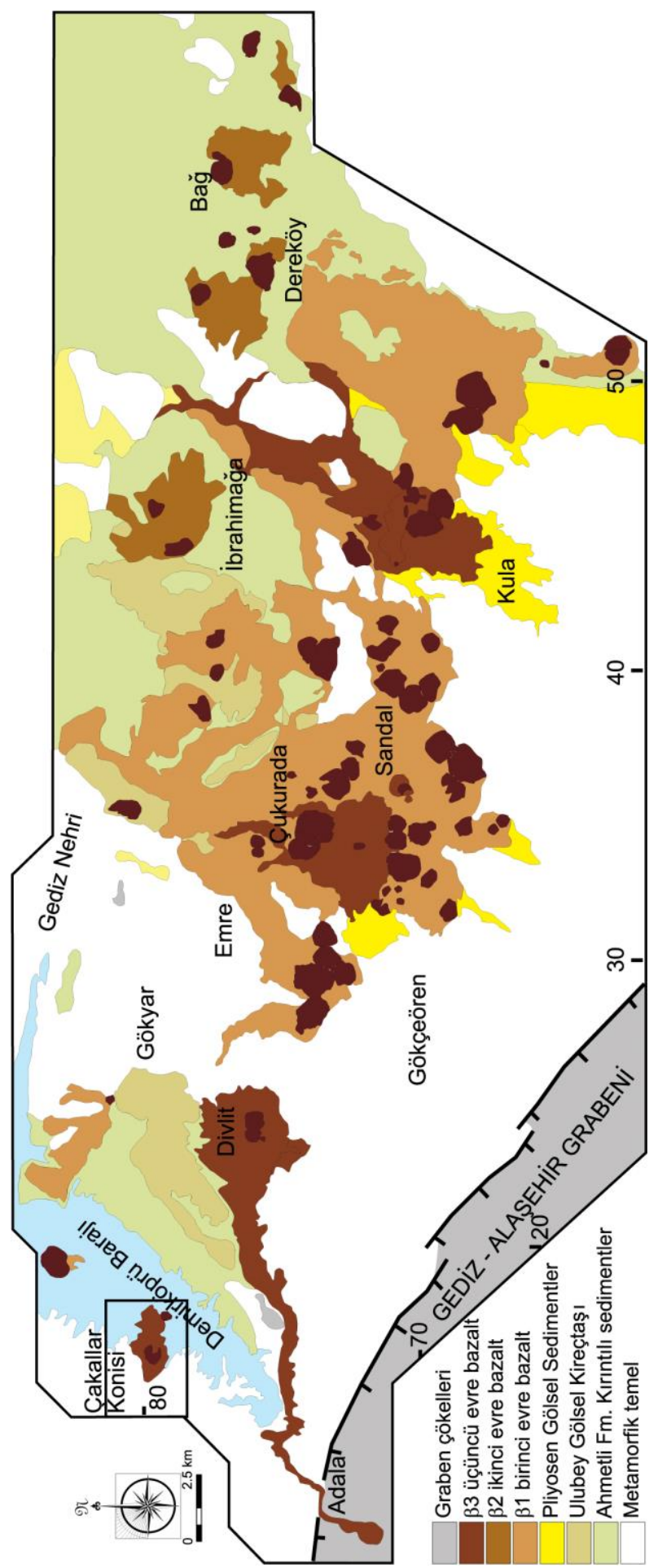

Şekil 2. Kula Na-Alkali volkanizmasının jeoloji haritası $([47,48,23]$ 'den yararlanılarak hazırlanmıștır). 

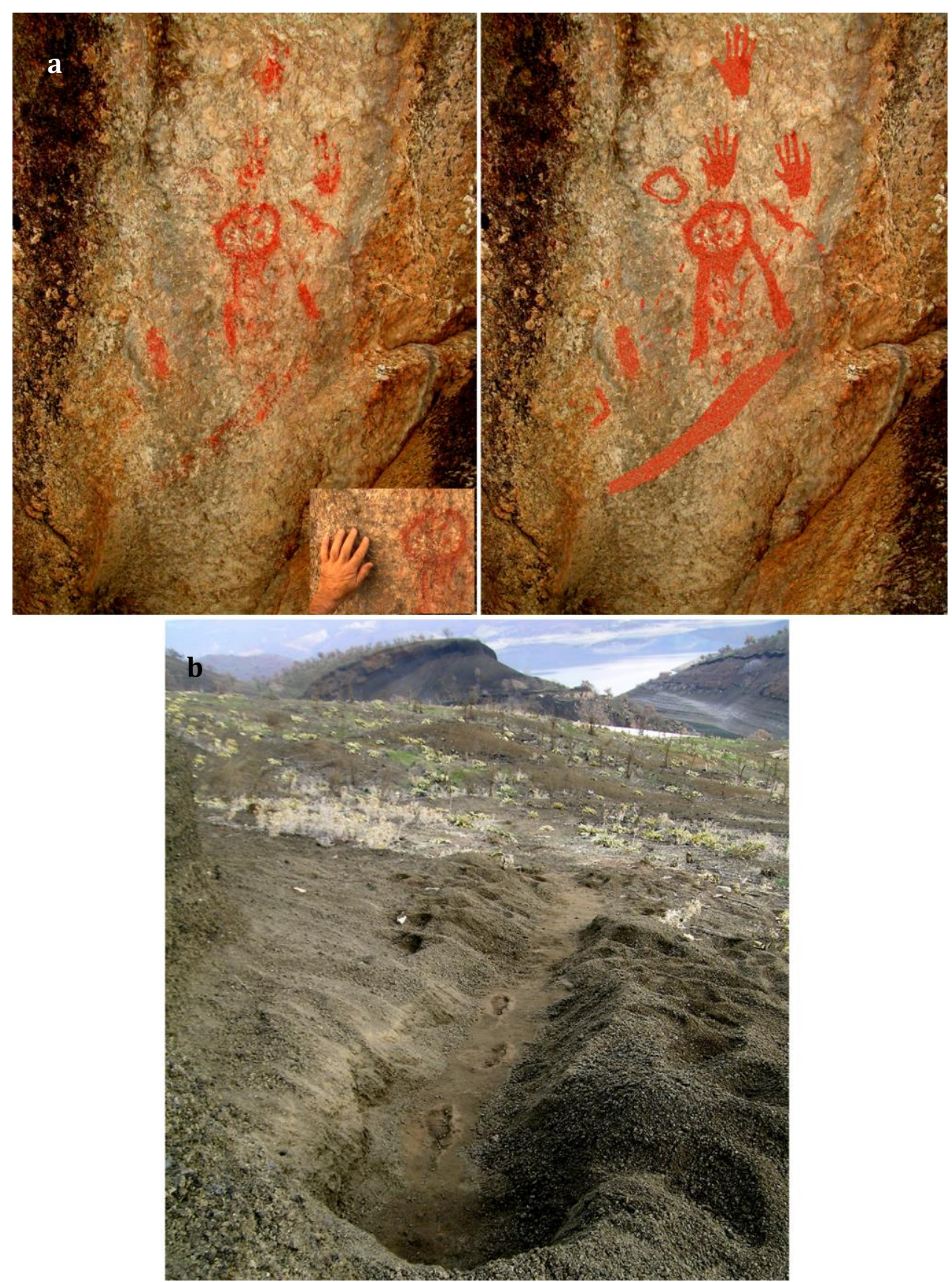

Şekil 3. a. Son evreye tanıklık eden Mezolitik dönem insanları, sığınak olarak kullandıkları gnayslar içindeki duvara şiddetli volkanik faaliyeti resimlemiş ve el izlerini bırakmışlardır. b. Yumuşak çamur kıvamına sahip piroklastik kül üzerine, Mezolitik dönemde yașamıș insanların Gediz nehri vadisine doğru inerken Çakallar Konisi'nin etrafında bıraktıkları ayak izleri. 
Araștırıcılara göre, volkanik sahanın batısında $15 \mathrm{~km}$ uzunluğundaki blok lav akıntısından alınan iki bazalt örneğinin ${ }^{3}$ Be yaşları $1.5 \pm 0.3$ ve $2.5 \pm 0.4$ ka'dır. Aynı lav akmasına ait bir gözlü gnays ksenoliti için ise $2.4 \pm 0.3 \mathrm{ka}{ }^{3}$ Be yaşı elde edilmiștir. Çalıșma alanını içeren ve Çakallar Tepe olarak adlandırılan kül konisinin tepesinden alınan bir metasedimenter ksenolitinden yapılan ${ }^{10} \mathrm{Be}$ yaşlandırması, bu koninin son püskürme yaşının $11.2 \pm 1.1 \mathrm{ka}$ olduğunu göstermiştir [33]. Çalışma alanında yer alan ve Anadolu'nun erken dönemlerdeki sakinlerinin bu volkanik patlamalardan etkilendiğini gösteren ayak izleri ve duvar resminin de (Kanlı Kaya) aynı zaman aralığını yansıttığı düşünülmektedir.

\section{4. Çakallar monojenik sinder konisi ve piroklastik çökelleri}

Kula volkanitlerinin yayılım sunduğu alanın en batısında, Manisa il sınır içinde Adala ile Köprübașı arasında Demirköprü baraj gölü batı kıyısında Çarıklı ve Sindel yerleșim alanında bulunan Çakallar monojenik sinder konisi ve piroklastitleri yaklaşık $5 \mathrm{~km}^{2}$ lik bir alanı kaplamaktadır (Șekil 4b).

Kula volkanizmasının en son ürünlerinden biri olan Çakallar Konisi'nin doğu bölümü volkanik faaliyet sırasında çöktüğü için hilal şeklinde gözlenmektedir. Çökmeye neden olan yoğun lav çıkışı Gediz nehri vadi yamacının eğimi etkisiyle doğuya doğru akmıștır. Lav akmalarının tam yayılımı bugün baraj gölü altında kalması nedeni ile gözlenememektedir. Çakallar Konisi'nin hemen güney yamacında küçük kül konisi (Hornito) ve yaklaşı $1.5 \mathrm{~km}$ batısında Küçük Divlit olarak bilinen iki küçük koni yer almaktadır. $\mathrm{Bu}$ iki lav çıkışına ait koniler Cakallar Konisi'nin piroklastitleri ve lav akmaları tarafından çevrelenmekte ve örtülmektedirler. [35] tarafından saptanan bu özellikleri ile iki küçük koni ve hatta Çakallar Konisi'nin kalın piroklastik ve lav akmalarını üreten ana Çakallar volkanik patlamasının önceki evrelerine ait oldukları açıç̧a görülmektedir.

Çakallar Monojenik Sinder Konisi'nin (Șekil 4a) gelişimi tek evreli olmadığı ve birden fazla farklı şiddette püskürme evreleri içerdiği yapılan arazi gözlemlerinde de ortaya konmuștur. İlk evre, birbirine yakın noktalardan püsküren piroklastik külce zengin patlama evresidir. $\mathrm{Bu}$ evrede, mm ve mikron boyutunda volkanik cam ve mineral kırıntılarınca zengin, piroklastik püskürmeyle yükselen kül bulutundan yağan küller Menderes Masifi metamorfik temelini örtmüștür (Şekil 4b,c ve 5a).

Devam eden sürede piroklastik malzemece zengin volkanik faaliyetin buhar fazı ile etkileşen piroklastik kül yı ğıșım lapillilerini olușturmuș ve yaklaşık $10 \mathrm{~cm}$ kalınlığa sahip ilk kül tabakası üzerine yağmışlardır. Yığıșım lapillileri yüzlerce metrekarelik alanı kaplamaktadır (Şekil 5b). Volkanik aktivitenin yavaşlaması ile birlikte havada asılı bulunan çok ince kül yığınları zamanla çökelerek yığışım lapillilerini tamamen örtmüşlerdir (Şekil 5c). İlk evrelerde oluşan kül tabakası, volkanizmanın tekrar șiddetini arttırarak aktif hale gelmesi ile birden fazla patlama noktasından türeyen kalın cüruf ve volkan bombasınca baskın 1-30 cm arasında lav parçalarından oluşan piroklastik çökeller tarafından örtülmüştür (Şekil 5d). Bu evreye ait piroklastik istif, bileşenlerinin büyük boyutlarda olması nedeniyle geniș alanlara yayılmamıș, çıkıș merkezlerine yakın alanları kaplamıș ve ilk birikim konilerini (sinder koni) olușturmuștur. Çakallar Konisi ilk çatısı ile doğusundaki Küçük Divlit Konisi ve hemen güneyinde küçük ölçekli parazit koni (hornito) bu evrede gelișmiștir. Çakallar Konisi'ne şeklini veren son volkanik aktivitede, piroklastik ve lav püskürmesi gerçekleşmiştir (Şekil 5d). Aktivite sırasında gelişen yoğun lav çıkışı ve akması koninin doğu bölümünü așındırarak çökmesine neden olmuştur. Hilal şeklinde yapı kazanan koniden yayılan lavlar yamaç aşağı Gediz nehri vadisine doğru akmış ve bu akmalar bir önceki evreye ait Küçük Divliti çevrelemiştir (Şekil 5d). Bu evredeki șiddetli püskürmeler ile 1-2m boyutlarındaki lav bombaları ve temele ait mermer, kuvarsit ve gnays parçaları yakın mesafelere firlatılmıştır (Şekil 7). Çok şiddetli volkanik faaliyet, o dönemde ayak izlerini bırakan insan toplulukları tarafindan gnays içindeki sı̆̆ınaklarından gözlenmiş ve aktivite sığınak duvarlarına resmedilmiștir (Şekil 3). Bu resimlemelerin olduğu yer Kula-Jeopark alanı içinde "KANLI KAYA" olarak bilinmektedir. 


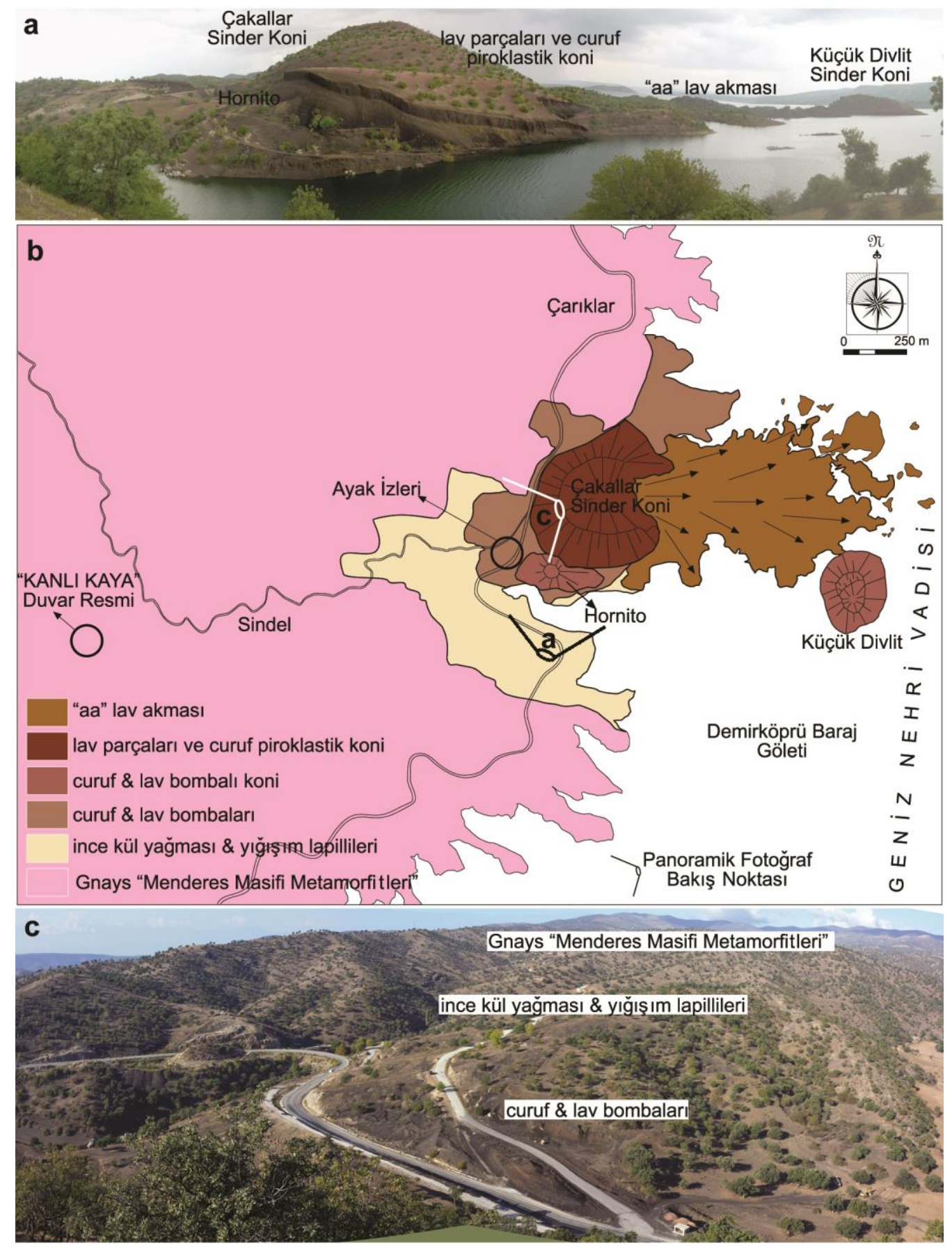

Şekil 4. a. Çakallar Monojenik Sinder Konisi. b. Bölgenin jeolojisi ve çoklu evre aktiviteye ait piroklastitlerin yayılımı. c. Çakallar Konisi'nin tepe noktasından batı bakış açılı panoramik görüntü. 


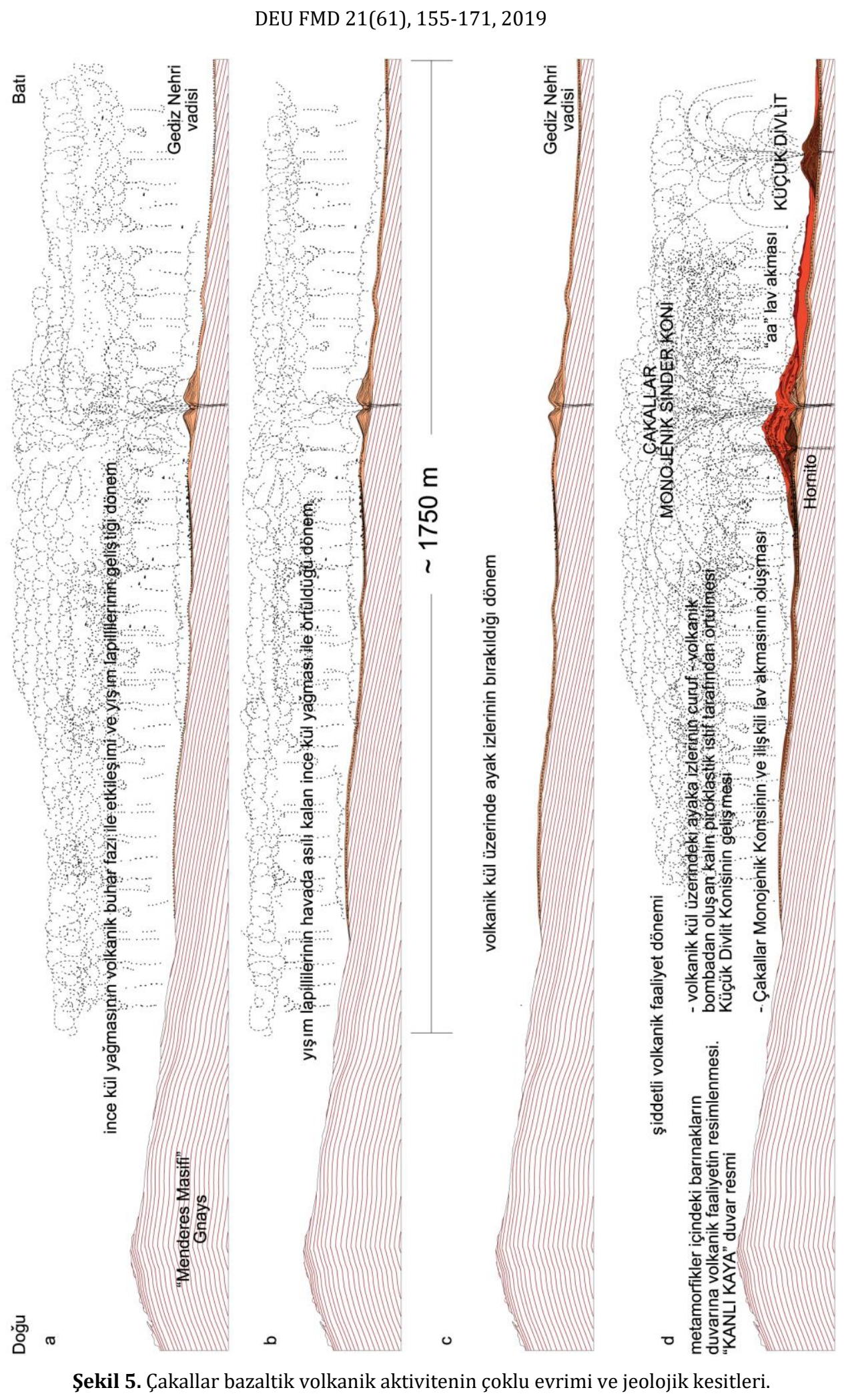



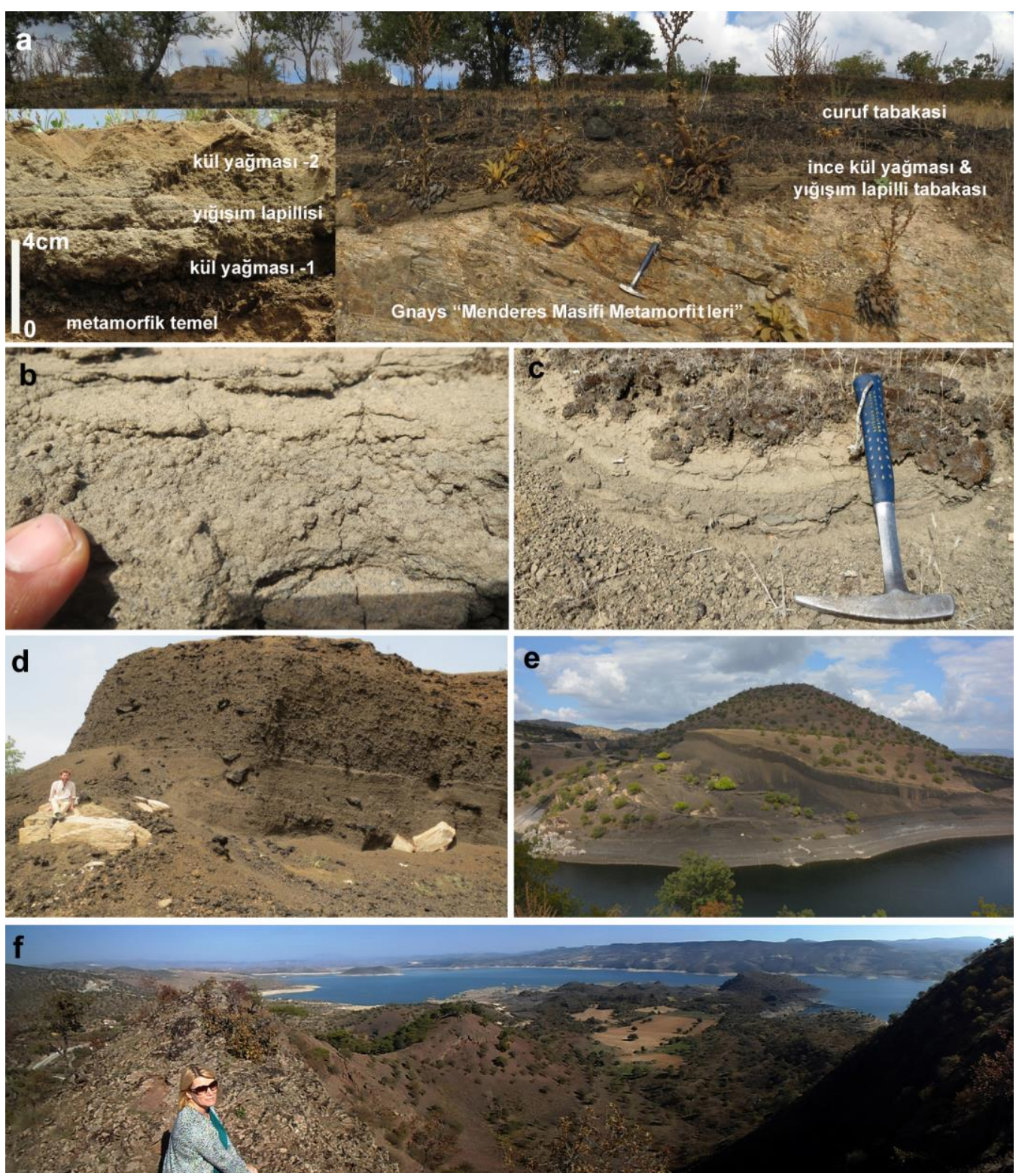

Şekil 6. Çakallar bazaltik volkanik aktiviteye ait piroklastik çökeller ve Çakallar Konisi'nin saha fotoğrafları. a. Menderes Masifi metamorfik temeline ait gnaysları örten yığışım lapilli içerikli kül tabakası ve üzerine gelen cüruf-lav parçaları içeren piroklastik döküntü. b-c. Yığıșım lapilli tabakası ve ayak izlerini içeren ince lapilli tabakasını örten ince kül yağması. d. İkinci volkanik aktivite evresini temsil eden cüruf-lav parçalı kalın piroklastik döküntü. e. Çakallar Konisi. f. Çakallar Konisi tepesinden doğu bakışlı panoramik görüntü. Koninin doğu bölümünün şiddetli lav akması ile aşındırılarak çökmesi sonucu Çakallar Konisi hilal şeklindedir. Koniden yayılan lav akması Gediz nehri vadisine doğru akmıştır. 


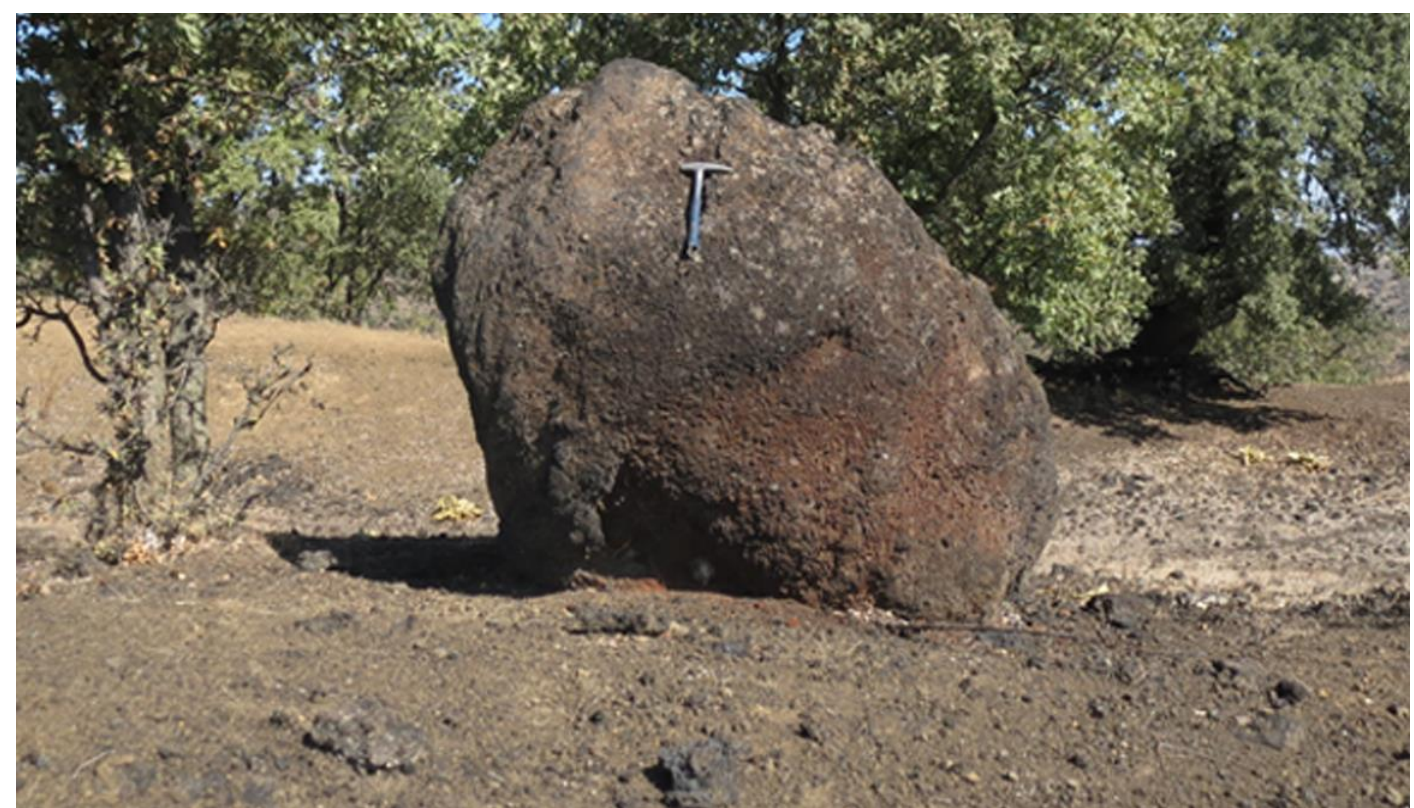

Şekil 7. Çakallar volkanik aktivitesinin son șiddetli evresinde volkan bacasından firlatılmıș metrik volkan bombası.

\section{Yığıșım lapillileri (acceleration lapilli)}

Gnaysları örten kül tabakası arasında (ilk evre kül yağması) ortalama $5 \mathrm{~cm}$ kalınlık sunan araları ince kül ile bağlanmış yığışım lapilli düzeyinden (Şekil 6b ve c) alınan örneklerin makroskobik ve mikroskobik olarak detaylı incelemeleri gerçekleştirilmiştir. Volkanik kül yağması ile oluşan ilk kül tabakası, sıcak olmayan, çok islak-cıvık veya kuru-gevşek olmayan, nemli ve sertçe bir örtü halinde yüzeyi kaplamıștır. Kül tabakasının üzerine düșen yığıșım lapillileri tabaka içine gömülmemiş, sadece yüzeyde izler bırakacak şekilde tabakayı etkilemiştir (Şekil 8a). Yığışım lapillileri oldukça iyi pekleşmiştir, yani parmaklar arasında ezmek oldukça güçtür. Yığışım lapillileri tam küresel ve düz yüzeylere sahiptir ve çapları 3 ile $6 \mathrm{~mm}$ arasında değișmektedir (Şekil 8a, 8b). Örneklerin yüzey rengi değişimleri çok az veya hiç yoktur. Yığışım lapillileri suda bekletildiğinde ayrışmamakta ve hidroklorik asit ile reaksiyona girmemektedir. 

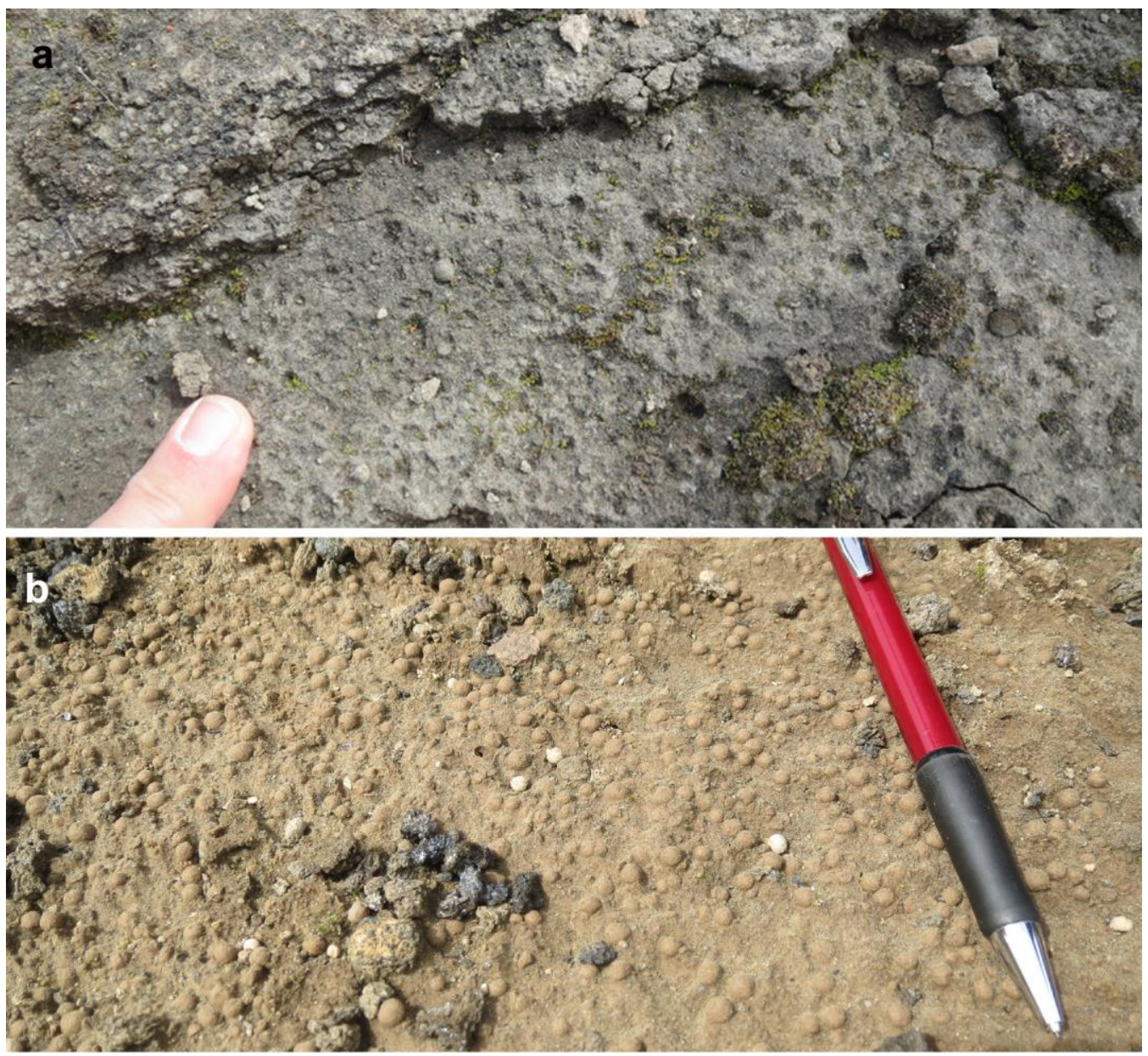

Şekil 8 a. Yığışım lapilli düzeyi içeren ilk evre kül boyutundaki piroklastik çökeller. İlk kül tabakası üzerine düşen yı ğışım lapillilerinin bıraktıkları izler. b. Kül ile bir arada eş boyutlu olarak bulunan yığıșım lapillice zengin tabakanın üstten görünümü.

Çok sayıda yı̆̆ışım lapillisi örneği epoksi reçine içine gömülerek kalıplandırılmış ve iç yapılarını gözlemlemek için yarıya kadar aşındırılarak petrografik ince kesitleri hazırlanmıștır. tek bir taneden çıkan kül malzeme binoküler altında incelenerek mineral ve volkanik parça bileşeni araştırılmıștır. 

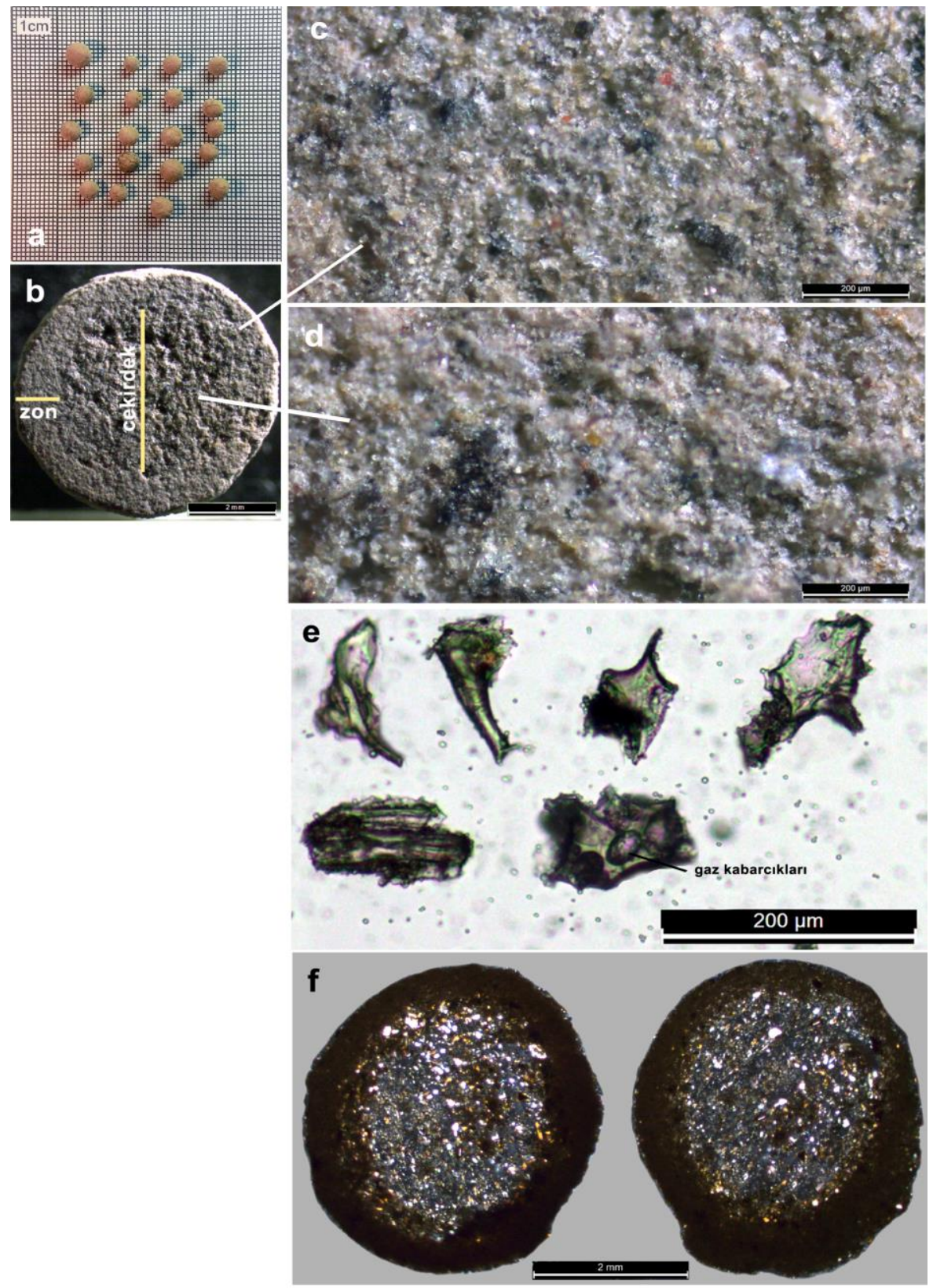

Şekil 9. Yığışım lapillilerine ait makroskobik ve mikroskobik ölçekli fotoğraflar. a. Eş tane boylu mükemmel küresel yığışım lapillileri. b. Yarısı aşındırılmış zon-tipi yığışım lapillinin çekirdek ve dış zondan oluşan iç yapısı. Bileșenlerini mineral kırıntıları ve volkanik cam oluşturmaktadır. Dış zon (c) ve iç çekirdeğin (d) n binoküler mikroskop altındaki görüntüleri. Her iki bölümün bileşenlerini magmatik kristal parçaları ve patlama sırasında kül bulutu içinde katılaşarak camlaşan lav parçaları oluşturmaktadır. e. Yığışım lapillileri içinde gözlenen volkanik cam parçaları. f. Yığışım lapillilerinin polarizan mikroskop altındaki görüntüleri. İç çekirdek dış zona göre daha ince taneli külden oluşmuştur. İç çekirdekte piroksen (sarı-turuncu renkli parçalar), plajiyoklas, volkanik cam ve çevre kayaçlardan koparılmış kuvars taneleri gözlenebilmektedir. 
Örneklerin merkezinde tek bileșen halinde volkanik litik parçadan (cam ve/veya mineral) oluşan bir çekirdek gözlenmemiştir. Taneler tamamen mikron boyutunda mineral ve cam parçalarınca zengindir. Yığıșım lapilli tanelerinin tümü karakteristik eş merkezli iki katmana sahiptir (Sekil 9b ve f). Bu katmanlar arasında dokusal açıdan belirgin gözenek farklılığı olup hafif de olsa renk ve mikronize haldeki kül tane boyunda değişim gözlenmektedir (Şekil 9c ve d).

Çakallar Sinder Konisi'ne ait kül çökellerinden alınan yığışım lapillilerinin ince kesitlerinde merkez kısımları tüm ölçeklerde homojen özellik sunmaktadır. Genelde lapilli içinde gözlenen kırıntılar merkezde daha iri iken kenara doğru oldukça incelmektedir (Şekil 9b,c ve d). Lapilli örneklerinin tümü neredeyse tamamen çok ince kül taneli veya camsı doku sunan bir dış halkaya sahiptir. Yığışım lapillilerinin merkezinde yer alan tane bileșenlerinin plajiyoklas, piroksen kristalleri, cam ve patlama sırasında metamorfik temelden kopartılmış kuvars kristal parçaları ile çok az oranda boşluklar bulunmaktadır. Çoğu cam parçaları, içbükey yüzeylere sahiptir, bu da bu yüzeylerin kabarcıklara ait duvarların bir parçası olduğunu göstermektedir (Șekil 9e). Bunun yanında gaz kabarcıklarının yer yer korunduğu volkanik cam parçalar da bulunmaktadır (Şekil 9e).

\section{Tartışma ve Sonuçlar}

Çalışma alanını kapsayan Kuvaterner yaşlı Çakallar Sinder Konisi'ni üreten piroklastik püskürme, kosmojenik yașlandırma ile de desteklenmiş (11.2 \pm 1.1 ka; [33]) ve Kula volkanizmasının en son evresi ürünüdür. Piroklastik ve lav akmasından olușan Çakallar Konisi hilal şeklini koninin doğu bölümünü aşındıran şiddetli lav akmaları ile kazanmıştır. Çakallar volkanizması olarak da tanımlanan $\mathrm{Na}-$ alkali bazaltik volkanizma şiddeti az patlamalıpiroklastik püskürme ürünü ince kül yağması ile başlamıştır ve geniş bir alanı kaplamıștır. Bu kül tabakası çok katmanlı olup kül tabakaları arasında kül ara maddeli eş boyutlu mükemmel küresel yığışım lapillice zengin $5 \mathrm{~cm}$ kalınlığa ulaşan bir ara tabaka bulunmaktadır. Daha sonraki patlamayla yığıșım lapillilerin üzeri çok ince kül tabakasıyla örtülmüştür. Bu üst kül tabakası çökelimi sonrasında bünyesindeki nem

merkeze yakın zonlar boyunca "kart destesi (stack of cards)" dokusu sunmaktadır [4]. Tane oranına bağlı olarak yumuşak çamur kıvamına sahip olduğu anda, Mezolitik dönemde yaşamış insanlar Gediz nehri vadisine doğru inerken Çakallar Konisi'nin etrafındaki bu kül tabakası üzerinde mükemmel şekilli ayak izlerini bırakmışlardır. Çakallar volkanik aktivitesi şiddetini arttırarak birden fazla noktadan püskürerek faaliyetlerine devam etmiştir. Volkanizmanın ikinci ana evresi, yakın mesafelere (proximal) yayılmış cüruf-lav-volkan bombalarından oluşan kalın piroklastik istif ve küçük ölçekli koniler ile temsil edilmektedir. Çakallar volkanik aktivitesinin en son şiddetli evresinde, Çakallar konisi son șeklini almış ve metre boyutuna ulaşan volkan bombalarını yakın mesafelere firlatmıştır. Volkanik faaliyetin sahip olduğu şiddeti ifade eden metrik boyutlardaki gnays bloklar temelden kopartılarak püskürme sırasında yakın çevreye firlatılmıştır. Son evreye tanıklık eden Mezolitik dönem insanları sığınak olarak kullandıkları gnayslar içindeki duvara şiddetli volkanik faaliyeti resimlemiş ve el izlerini bırakmışlardır.

$[8,4]$ yapısal olarak iki farklı yığıșım lapilli tipi tanımlamışlardır: (1) İnce taneli bir dış zon ile çevrili ve bu dış zona göre daha iri taneli bir merkeze sahip olan zon (kenar)-tipi lapilli; ve (2) sadece iri taneli bir çekirdek içeren ve bir kenar zonu olmayan çekirdek-tipi lapilli. Her iki tip de kül yağışı, piroklastik akma ve taban türbülans çökellerinde (surge deposits) meydana gelebilmektedir.

Yığışım lapillisinin oluşum şekilleri, piroklastik çökellerin yapısı, kütle hareketi, bileșenlerinin tane boyutu özellikleri ve stratigrafik ilişkilerine bağlı farklılıklar göstermektedir [4]. Örneğin, piroklastik kül çökellerinde zon veya çekirdektipi lapilli stratigrafik olarak çökelin tabanında yoğunlaşırken, piroklastik akma ve taban türbülans çökellerinde patlamanın yakın mesafesinde (proximal) kenar-tipi, uzak mesafesinde (distal) ise çekirdek-tipi lapilli gözlenmektedir. Gözeneklilik sunan veziküler tüflerde sadece çekirdek-tipi lapilli ortaya çıkmaktadır. Yığışım lapilli taneleri taban türbülans çökellerinde piroklastik akma çökellerine göre daha iyi boylanmış ve daha küçüktür [4]. İç yapılarına göre yığışım lapillileri piroklastik akma çökellerinde disk şekilli iken, taban türbülans çökellerinde küreseldir. Kül çökellerinde gözlenen yığışım lapillilerin tane içi dokusu ise merkez ve

boyu dağılımı açısından da yığışım lapillileri ortamsal olarak farklılık göstermektedir. Kül 
çökellerinde maksimum $250-350 \mu$ m tane boyu ile birlikte tek bileşenli (unimodal) bir dağılım vardır. Piroklastik akma çökellerinde ise zontipi ve çekirdek-tipinde olup maksimum tane boyu 350-500 $\mu \mathrm{m}$ 'dur. Taban türbülans çökellerinde ise daha iri tane boyu gözlenmektedir (maks. $2 \mathrm{~mm}$ ) ve genelde tek bileșenli ve zayıf olarak da iki bileșenli dağılım sözkonusudur [4].

Çakallar Konisi'ne ait yığışım lapillileri bol miktarda cam parçalar içermektedir. $\mathrm{Bu}$ da bu malzemenin patlama sırasında lavların parçalanması ve kül șeklinde püskürmesiyle oluștuğunu göstermektedir. Dinamik bir püskürme sütunu ve kül bulutu ortamında farklı boyutta tane türleri ve bolluğu (kristal parçaları, cam kırıkları ve kaya parçaları) ortaya çıkmıştır. $\mathrm{Bu}$ bileșenlerin oldukça değișken olması da yığışım lapillilerinin gelişmesinde oldukça etkin rol oynamıștır. Buna göre Çakallar Sinder Konisi'ne ait kül çökellerinden alınan örneklerin ince kesit incelemelerinde bölgedeki yığıșım lapillilerinin [4]'in sinıflamasına göre zon-tipi yığışım lapilli olduğu saptanmıştır.

\section{Teşekkür}

Makaleye yapmış oldukları değerli katkılardan dolayı isimleri belirtilmemiş 3 hakeme teșekkür ederiz. Ayrıca Şekil 3b'de kullanılan fotoğraf Prof. Dr. Hülya İnaner'in fotoğraf arşivinden alınmıștır.

\section{Kaynakça}

[1] Moore, J.B., Peck, D.L. 1962. Accretionary lapilli in volcanic rocks of the western continental United States. Journal of Geology, Cilt. 70, ss. 182-193.

[2] Gilbert, J.S., Lane, S.J. 1994. The origin of accretionary lapilli. Bulletin of Volcanology, Cilt. 56, ss. 398-411.

[3] Adams, P.M., Lynch, D.K., Buesch, D.C. 2016 Accretionary lapilli: what's holding them together? 2016 Desert Symposium, ss. 256-265.

[4] Schumacher, R., Schmincke, H.S. 1995. Models for the origin of accretionary lapilli. Bulletin of Volcanology, Cilt. 56, ss. 626-639.

[5] Brown, R.J., Branney, M.J., Maher, C., Dávila-Harris, P. 2009. Origin of accretionary lapilli within groundhugging density currents: Evidence from pyroclastic couplets on Tenerife; Geological Society of America Bulletin, Cilt. 122 (1-2), s. 305-320. doi: 10.1130/B26449.1

[6] Lacroix, A. 1904. La Montagne Pel6e et ses eruptions: Paris, ss. 1-662.

[7] Lorenz, V. 1974. Vesiculated tufts and associated features. Sedimentology, Cilt. 21, ss. 273-291.

[8] Schumacher, R., Schmincke, H.S. 1991. Internal structure and occurrence of accretionary lapilli - a case study at Laacher See Volcano. Bulletin of Volcanology, Cilt. 53, ss. 612-634.

[9] Kittl, E. 1933. Estudio sobre los fen6menos volcfinicos y material cafdo durante la erupcion del grupo del "Descabezado" en el rues de abril de 1932. Anal Museo Nac Hist Nat (Buenos Aires), Cilt. 37, ss. 321-364.

[10] Sorem, R.K. 1982. Volcanic ash clusters: tephra rafts and scavengers. Journal of Volcanology and Geothermal Research, Cilt. 13, ss. 63-71.

[11] Gilbert, J.S., Lane, S.J., Sparks, R.S.J., Koyaguchi, T. 1991. Charge measurements on particle fallout from a volcanic plume. Nature, Cilt. 349, ss. 598-600.

[12] Lane, S.J., Gilbert, J.S., Hilton, M. 1993. The aerodynamic behaviour of volcanic aggregates. Bulletin of Volcanology, Cilt. 55, ss. 481-488.

[13] Güleç, N. 1991. Crust-mantle interaction in western Turkey: implications from $\mathrm{Sr}$ and $\mathrm{Nd}$ isotope geochemistry of Tertiary and Quaternary volcanics. Geological Magazine, Cilt. 128, ss. 417-435.

[14] Bunbury, J.M.R. 1996. The Kula Volcanic Field, western Turkey: the devolopment of a Holocene alkali basalt province and the adjacent normalfaulting graben. Geological Magazine, Cilt. 133 (3), s. 275-283.

[15] Seyitoğlu, G. 1997b. Late Cenozoic tectonosedimentary development of the Selendi and Uşak-Güre basins: a contribution to the discussion on the development of east-west and north trending basins in Western Turkey. Geological Magazine, Cilt. 134 , ss. $163-175$

[16] Aldanmaz, E., Pearce, J.A., Thirlwall, M.F., Mitchell, J.G. 2000. Petrogenetic evolution of late Cenozoic, post-collision volcanism in western Anatolia, Turkey. Journal of Volcanology and Geothermal Research, Cilt. 102, s. 67-95.

[17] Alıcl, P., Temel, A., Gourgaud, A. 2002. Pb-Nd-Sr isotope and trace element geochemistry of Quaternary extension-related alkaline volcanism: a case study of Kula region (western Anatolia, Turkey). Journal of Volcanology and Geothermal Research, Cilt. 115, s. 487-510.

[18] Purvis, M., Robertson, A. 2005. Miocene sedimentary evolution of the NE-SWtrending Selendi and Gördes basins, western Turkey: implications for extensional processes. Sedimentary Geology, Cilt. 174, ss. 31-62.

[19] Westaway, R., Pringle, M., Yurtmen, S., Demir, T., Bridgland, D., Rowbotham, G., Maddy, D. 2004. Pliocene and Quaternary regional uplift inwestern Turkey: the Gediz River terrace staircase and the volcanism at Kula. Tectonophysics, Cilt. 391, ss. 121169.

[20] Tokçaer, M., Agostini, S., Savaşçın, M.Y. 2005. Geotectonic setting and origin of the youngest Kula volcanics (Western Anatolia), with a new emplacement model. Turkish Journal of Earth Sciences, Cilt. 14, ss. 145-166.

[21] Innocenti, F., Agostini, S., di Vincenzo, G., Doglioni, C., Manetti, P., Savaşçın, M.Y., Tonarini, S. 2005. Neogene 
and quaternary volcanism in Western Anatolia: Magma sources and geodynamic evolution. Marine Geology, Cilt. 221, ss. 397-421.

[22] Holness, M. B., Bunbury, J. M. 2006. Insights into continental rift-related magma chambers: Cognate nodules from the Kula Volcanic Province, Western Turkey. Journal of Volcanology and Geothermal Research, Cilt. 153, ss. 241-261.

[23] Westaway, R., Guillou, H., Yurtmen, S., Beck, A., Bridgland, D., Demir, T., Scaillet, S., Rowbotham, G. 2006. Late Cenozoic uplift of western Turkey: improved dating of the Kula Quaternary volcanic field and numerical modelling of the Gediz River terrace staircase. Global and Planetary Change, Cilt. 51, ss. $131-171$

[24] Coban, H. 2007. Basalt magma genesis and fractionation in collision and extension related provinces: a comparison between eastern, central and western Anatolia. Earth Science Reviews, Cilt. 80, s. 219-238.

[25] Ersoy, E., Helvacl, C. 2007. Stratigraphy and geochemical features of the Early Miocene bimodal (ultrapotassic and calc-alkaline) volcanic activity within the NE-trending Selendi Basin, Western Anatolia, Turkey. Turkish Journal of Earth Science, Cilt. 16, s. 117-139.

[26] Ersoy, E.Y., Helvacı, C., Sözbilir, H., Erkül, F., Bozkurt, E. 2008. A geochemical approach to NeogeneQuaternary volcanic activity of western Anatolia: an example of episodic bimodal volcanism within the Selendi Basin, Turkey. Chemical Geology, Cilt. 30, s. 265-282.

[27] Ersoy, E.Y., Helvacl, C., Palmer, M.R. 2011 Stratigraphic, structural and geochemical geochemical features of the NE-SW-trending Neogene volcano-sedimentary basins in western Anatolia: implications for associations of supradetachment and transtensional strike-slip basin formation in extensional tectonic setting. Journal of Asian Earth Sciences, Cilt. 41, s. 159-183.

[28] Ersoy, E.Y., Helvacl, C., Palmer, M.R. 2012. Petrogenesis of the Neogene volcanic units in the NE-SW-trending basins in western Anatolia, Turkey. Contributions to Mineralogy and Petrology, Cilt. 163, s. 379-401.

[29] Karaoğlu, Ö., Helvacl, C., Ersoy, E.Y. 2010 Petrogenesis and 40Ar/39Ar Geochronology of the Volcanic Rocks of the Ușak-Güre basin, western Türkiye. Lithos, Cilt. 119, ss. 193-210.

[30] Grützner, T., Prelevic, D., Akal C. 2013. Geochemistry and origin of ultramafic enclaves and their basanitic host rock from Kula Volcano, Turkey. Lithos, Cilt. $180-181$, ss. $58-73$.

[31] Şen, E., Aydar, E., Bayhan, H., Gourgaud, A. 2013. Kula Volkanik Alanı'nın (Batı Anadolu) Fiziksel Volkanolojis (Physical volcanology of Kula Volcanic Field, western Anatolia). İ.T.Ü. Avrasya Yerbilimleri Enstitüsü.

[32] Şen, E., Aydar, E., Bayhan, H., Gourgaud, A. 2014. Alkali Bazalt ve Piroklastik Çökellerin Volkanolojik
Özellikleri, Kula Volkanları, Batı Anadolu (Volcanological characteristics of alkaline Basalt and Pyroclastic Deposits, Kula Volcanoes, Western Anatolia). Bulletin of Earth Sciences Application and Research Centre of Hacettepe Univ. Cilt. 35, ss. 219252.

[33] Heineke, C., Niedermann, S., Hetzel, R., Akal, C. 2016. Surface exposure dating of Holocene basalt flows and cinder cones in the Kula volcanic field (Western Turkey) using cosmogenic ${ }^{3} \mathrm{He}$ and ${ }^{10} \mathrm{Be}$. Quaternary Geochronology, Cilt. 34, ss. 81-91.

[34] Ozansoy, F. 1969. Türkiye pleistosen fosil insan ayak izleri. Maden Tetkik ve Arama Enstitüsü Dergisi, Cilt. 72, ss. 204-209.

[35] Kayan, I., 1992. Demirköprü baraj gölü batı kıyısında Çakallar volkanizması ve fosil insan ayak izleri. Ege Coğrafya Dergisi, Cilt. 6, ss. 1-34.

[36] Akal, C., Bulut, S., Kaya, T., Savaşçın, M.Y., Süvari, E.F., Türe, A. 2009. Turkey offers a new geopark to the world: Katakekaumene- Burnt Fires geopark Project. Geoturismo \& Desenvolvimento local (Geotourism \& Local Development), s. 138-149.

[37] Fytikas, M., Innocenti, F., Manetti, P., Mazzuoli, R., Peccerillo, A., Villari, L. 1984. Tertiary to Quaternary evolution of volcanism in the Aegean region, ss. 687699. Dixon, J.E., Robertson, A.H.F. ed. 1984. The Geological Evolution of the Eastern Mediterranean. Geological Society of London Special Publications 17, 825 s.

[38] Faccenna, C., Jolivet, L., Piromallo, C., Morelli, A. 2003. Subduction and the depth of convection in the Mediterranean mantle. Journal of Geophysical Research. Cilt. 108 (B2), s. 2099. http:// dx.doi.org/10.1029/2001JB001690.

[39] Brun, J.-P., Sokoutis, D. 2010. 45 m.y. of Aegean crust and mantle flow driven by trench retreat. Geology, Cilt. 38, s. 815-818.

[40] Prelević, D., Akal, C., Foley, S.F., Romer, R.L., Stracke, A., van den Bogaard, P. 2012. Ultrapotassic mafic rocks as geochemical proxies for post-collisional Dynamics of orogenic lithospheric mantle: the case of southwestern Anatolia, Turkey. Journal of Petrology, Cilt. 53, ss. 1019-1055.

[41] Seyitoğlu, G., Scott, B.C. 1991. Late Cenozoic extension and basin formation in West Turkey. Geological Magazine, Cilt. 128, ss. 155-166.

[42] Bozkurt, E., 2000. Timing of extension on the Büyük Menderes Graben, western Turkey, and its tectonic implications, ss. 385-403. Bozkurt, E., Winchester, J.A., Piper, J.D.A., ed. 2000. Tectonics and Magmatism in Turkey and the Surrounding Area. Geological Society of London Special Publications, 173, 521s.

[43] Purvis, M., Robertson, A. 2004. A pulsed extension model for the neogene-recent EW-trending Alas, ehir Graben and the NE-SW-trending Selendi and Gordes Basins, western Turkey. Tectonophysics, Cilt. 391, ss. 171-201.

[44] Thomson, S.N., Ring, U. 2006. Thermochronologic evaluation of postcollision extension in the Anatolide 
DEU FMD 21(61), 155-171, 2019

orogen, western Turkey. Tectonics, Cilt. 25, TC3005. http://dx.doi.org/10.1029/2005TC001833.

[45] Glodny, J., Hetzel, R. 2007. Precise U-Pb ages of synextensional Miocene intrusions in the centra Menderes Massif, western Turkey. Geological Magazine, Cilt. 144, ss. 235-246.

[46] Buscher, J.T., Hampel, A., Hetzel, R., Dunkl, I., Glotzbach, C., Struffert, A., Akal, C., Rätz, M. 2013. Quantifying rates of detachment faulting and erosion in the central Menderes Massif (western Turkey) by thermochronology and cosmogenic ${ }^{10} \mathrm{Be}$ Journal of Geological Society, London, Cilt. 170, s. 669-683.

[47] Ercan, T. 1993, Interpretation of geochemical, radiometric and isotopic data on Kula volcanics (Manisa-W.Anatolia), Geological Bulletin of Turkey, Cilt. 36, s. 113-129.

[48] Richardson-Bunbury, J.M. 1996. The Kula Volcanic Field, western Turkey: the development of a Holocene alkali basalt province and the adjacent normalfaulting graben. Geological Magazine, Cilt. 133, ss. 275-283.
[49] Yllmaz, Y. 1989. An approach to the origin of young volcanic rocks of western Turkey, ss. 159-189. Şengör, A.M.C. ed. 1989. Tectonic Evolution of the Tethyan Region. Kluwer Academic Publishers, 698s.

[50] Yllmaz, Y. 1990. Comparison of young volcanic associations of western and eastern Anatolia formed under a compressional regime: a review. Journal of Volcanology and Geothermal Research, Cilt. 44, ss. 119.

[51] Bunbury, J.M., Hall, L., Anderson, G.J., Stannard, A. 2001. The determination of fault movement history from the interaction of local drainage with volcanic episodes. Geological Magazine, Cilt. 138, s. 185-192.

[52] Borsi, S., Ferrara, G., Innocenti, F., Mazzuoli, R. 1972. Geochronology and petrology of recent volcanics in the Eastern Aegean Sea (West Anatolia and Lesvos Island). Bulletin of Volcanology. Cilt. 36, s. 473-496.

[53] Göksu, H.Y. 1978. The TL age determination of fossil human footprints. Archaeo-Physika, Cilt. 10, ss. 455462. 